\title{
PKM kerajinan Inu dan kerupuk sagu Siberut Selatan Kabupaten Kepulauan Mentawai
}

\author{
Alfattory Rheza Syahrul*, Kaksim, dan Jimi Ronald \\ STKIP PGRI Sumatera Barat \\ * alfattoryrsy@gmail.com
}

\begin{abstract}
Abstrak. Kegiatan Pengabdian ini memberikan Pelatihan dan pendampingan peningkatan penjualan dan proses produksi serta penggunaan media aplikasi E Commerce sebagai media sarana untuk pemasaran yang tepat bagi kelompok usaha Melati 2 di Dusun Batjoja Kep Mentawai. Target dari kegiatan ini adalah: 1) Kelompok usaha mendapat pengetahuan dan pemahaman mengenai konsep dasar tentang peningkatan produksi dan penjualan. 2) Kelompok usaha memiliki pengetahuan dan pemahaman mengenai media promosi dengan menggunakan E Commerce. 3) Kelompok usaha dapat mengaplikasikan pengetahuan yang didapatkan dari pelatihan dengan keterampilan mengelola produksi dan Promosi yang tepat. Metode dalam kegiatan ini dengan menganalisa situasi masyarakat dengan memberikan beberapa kali pendampingan dan latihan dalam proses produksi dan promosi penjualan. Hasil yang diperoleh dari kegiatan pengabdian ini adalah Kelompok mitra Sangat antusias dalam berkegiatan dan ingin terus meningkatkan penjualan, tetapi masih terkendala dengan buruknya akses internet. Sehingga dalam menggunakan media online masih Sangat terkendala. Sementara untuk penjualan secara langsung sudah mengalami peningkatan pemesanan.
\end{abstract}

Kata kunci: promosi, penjualan, Inu Mentawai, kerupuk sagu, Desa Meillepet

\begin{abstract}
Activity the PPM team provided training and mentoring to increase sales and production processes as well as the use of E Commerce application media as a medium for the right marketing for Melati 2 in Batjoja Village, Mentawai Island. The target of this activity is. 1) The business group gets knowledge and understanding of the basic concepts of sales. 2) Business groups have the knowledge and understanding of promotional media using E Commerce 3) Business groups can apply the knowledge gained from training with the right skills in managing production and promotion. The method in this activity is to analyze the situation of the community by giving several times of mentoring and training in the production process and sales promotion. The results obtained from this service activity are partners Very enthusiastic in activities and want to increase sales, but are still constrained by internet access. So that in online promotion is still constrained. While for sales directly experience an increase in orders.
\end{abstract}

Keywords: promotion, sales, inu mentawai, sago crackers, Meillepet Village

To cite this article: Syahrul, A. R., Kaksim, \& J. Ronald. 2019. PKM kerajinan Inu dan kerupuk sagu Siberut Selatan Kabupaten Kepulauan Mentawai. Unri Conference Series: Community Engagement 1: 39-45.

https://doi.org/10.31258/unricsce.1.39-45

(C) 2019 Authors

Peer-review under responsibility of the organizing committee of Seminar Nasional Pemberdayaan Masyarakat 2019 


\section{PENDAHULUAN}

Perkembangan usaha mikro kecil dan menengah (UMKM) memiliki potensi yang besar dalam meningkatkan taraf hidup masyarakat dikarenakan sektor UMKM memiliki pasar yang luas dan mampu menyerap tenaga kerja sehingga dapat menekan tingkat pengangguran dan kemiskinan. Salah satu upaya pemerintah untuk memperkuat perekonomian saat ini adalah dengan terus memberdayakan Usaha Kecil dan Menengah (UMKM). Karena itulah pengembangan masyarakat dengan metode pendampingan sosial perlu dilakukan untuk membantu memecahkan persoalan yang sedang dihadapi.

Pengembangan Masyarakat mengandung upaya untuk meningkatkan partisipasi dan rasa memiliki terhadap program yang dilaksanakan. Pemberdayaan merujuk pada kemampuan seseorang, khususnya kelompok lemah untuk memiiki akses terhadap sumber-sumber produktif yang memungkinkan mereka untuk dapat meningkatkan pendapatannya dan berpartisipasi dalam proses pembangunan serta pengambilan keputusan (Murdani1 , Sus Widayani2, 2019)

Hal ini disebabkan karena sebagian besar atau hampir $99 \%$ UMKM di Indonesia adalah usaha mikro di sektor informal dan pada umumnya menggunakan bahan baku lokal dengan pasar lokal. Sehingga menyebabkan UMKM tidak terpengaruh secara langsung oleh krisis global. Berdasarkan obeservasi yang dilakukan pada Kelompok Usaha mikro Siberut selatan yang berada di Desa Meillepet Dusun Batjoja, kendala yang dihadapi Kelompok Usaha untuk mengembangkan usaha adalah masalah penjualan, kekurangan faktor produksi, distribusi pemasaran dan untuk pengenalan produk asli daerah ke masyarakat luar. Beberapa dari kendala yang dihadapi oleh usaha kecil tersebut telah dicoba dicari solusinya tetapi selalu mengalami kegagalan karena Kepulauan Mentawai merupakan salah satu daerah yang sangat sulit di jangkau oleh konsumen. Hasil produksi selama ini dijual sendiri, dititipkan di kantor perwakilan Dinas Pariwisata dan produksi berdasarkan pesanan, hanya mengandalkan pemasaran yang konvensional dan hanya menjangkau pelanggan di pasar lokal saja, minimal mampu menyuplai permintaan dari luar kota

Salah satu langkah untuk mengatasi permasalahan dalam aktivitas pemasaran adalah menggunakan media E Commerce sebagai sarana promosi yang tepat. Dalam (Harto et al., 2019) mengatakan website memberikan kemudahan mitra dalam melakukan kegiatan perdagangan. Mitra merasa mendapatkan efisiensi waktu, sehingga bisa dimaksimalkan dengan memikirkan diversifikasi produk. Penerapan teknologi internet dapat membantu meningkatkan omset dan perluasan usaha Berdasarkan kegiatan yang telah dilakukan oleh tim PKM bahwa wilayah Dusun Batjoja Kecamatan Siberut Selatan mempunyai potensi untuk mengembangkan usahanya. Kelompok Usaha kerajinan Inu dan makanan ringan Kerupuk Sagu ini sudah aktif menghasilkan produksi selama \pm 2 tahun. Usaha ini dikelola oleh pemilik secara berkelompok. Peminat dari kerajinan Inu dan makanan ringan Kerupuk Sagu ini sangat tinggi karena memiliki ciri khas tersendiri yang hanya di jumpai di kepulauan Mentawai.

Kelompok Usaha yang menjadi mitra dalam pengabdian ini adalah kelompok Melati 2 yang bergerak di bidang Usaha kerajinan Inu dan Usaha Kerupuk sagu. Kerajinan inu merupakan aksesoris khas masyarakat Mentawai khususnya di Siberut. Kerupuk sagu adalah makanan olahan yang berbahan utama sagu kemudian menjadi makanan olahan berupa kerupuk sagu. Terdapat 5 kegiatan penting yang dapat dilakukan dalam melakukan pendampingan yaitu adanya motivasi, peningkatan kesadaran dan kemampuan, manajemen diri, mobilisasi sumber, pembangunan dan pengembangan jaringan. (Murdani1 , Sus Widayani2, 2019)

Alasan pemilihan Kelompok Usaha ini menjadi mitra karena Kelompok Usaha ingin mengembangkan usahanya secara konsisten dan terus menerus, belum pernahnya Kelompok Usaha kerajinan Inu dan Usaha Kerupuk Sagu mendapatkan pelatihan dan pendampingan proses produksi dan cara penggunaan media online sehingga Kelompok Usaha tersebut mampu meningkatkan penjualannya dan meningkatkan produksinya. Problema yang sering dihadapi mitra usaha ini yaitu masalah penjualan kerajinan Inu dan Kerupuk Oleh sebab itu penting kiranya Kelompok Usaha ini mengetahui dan memahami sistematika penggunaan media online dalam hal ini penggunaan E Commerce, sehingga dapat memaksimalkan penjulannya dan dapat meningkatkan produksinya sehingga dapat diketahui jumlah laba atau rugi yang diperoleh dari penjualan tersebut.

Pemasaran melalui internet seperti e commerce memberikan manfaat dan kemudahan bagi para pelanggan yang mengunakan sistem belanja online dan secara positif mempengaruhi minat pelanggan online untuk berbelanja pada produk yang ditawarkan (Reimers et al., 2016). Untuk itu Kelompok Usaha kerajinan Inu dan Kerupuk Sagu ini membutuhkan pelatihan dan pendampingan dalam kegiatan produksi serta penggunaan media E Commerce yang intensif sehingga dapat meningkatkan penjualan dan meningkatkan produksinya. Tujuan dari kegiatan ini adalah bagaimana nantinya kelompok melati 2 menjadi kelompok usaha percontohan bagi kelompok yang lain di Desa Meillepet. 


\section{METODE PENERAPAN}

Dalam pelaksanaan PKM kerajinan Inu dan kerupuk sagu Siberut Selatan metode pelaksanaan yang dilakukan adalah:

1. Penyuluhan dan pendampingan bagi kelompok mitra yang telah di tentukan yakni kelompok melati 2 . Dalam hal ini kelompok mendapatkan bimbingan dan pembinaan yang baik guna memperoleh pendampingan bagaimana melakukan proses produksi yang tepat serta pemilihan saluran pemasaran. Dalam proses pendampingan meliputi pemilihan bahan utama yang telah ditentukan dalam hal ini dari kerajinan inu serta kerupuk sagu. Pemilihan motif kerajinan yang dipakai dalam kerajinan tetap dalam mempertahankan budaya lokal. Serta sagu yang berkualitas. Cara pengolahan yang tepat, dan pengemasan yang menarik.

2. Persiapan dan pendataan peserta pelatihan. Persiapan dilakukan dalam rangka mempersiapkan peserta, mempersiapkan pelatih, bahan yang diperlukan, dan tempat pelatihan, serta memastikan jadwal.

3. Pendampingan akan berperan aktif dalam memberikan materi pelatihan dan praktik memproduksi pembuatan kerajinan inu dan kerupuk sagu mentawai, terutama dalam hal teknik pembuatan dan kreasinya sehingga hasil produksinya bagus dan bisa menarik pasar

4. Pendampingan Pemasaran produk. Selama ini kelompok mitra dalam menghasilkan kerajinan dan kerupuk sagu terkendala dengan kemana mereka akan pasarkan hasil produksi mereka. Kedepannya mitra dapat memasarkan produk dan memenuhi pesanan dari masyarakat local ataupun mancanegara. Solusi untuk pemasaran ini dengan menyediakan pondok promosi dan mengunakan saluran promosi dengan membuat marketplace yakninya dengan nama Melati 2.

Selama pelaksanaan kegiatan tim pengusul selalu berkoordinasi dengan mitra sehingga dalam prosesnya mitra memahami dan dapat menjalankan secara mandiri atas teknologi yang telah ditransfer melalui kegiatan pelatihan dan pendampingan secara intensif dari masing masing kegiatan. Kegiatan pendampingan dilaksanakan untuk memberikan gambaran kepada mitra sebelum kegiatan dimulai. Dalam pelaksanaan program ini tim akan selalu mengevaluasi dan melaporkan setiap kegiatan yang telah dilaksanakan sampai semua kegiatan terealisasi. Sehingga kerjasama antara tim dan mitra dapat terwujud. Dan masing masing anggota tim dapat mengoptimalkan potensi dan bidang dipakarnya.

\section{HASIL DAN KETERCAPAIAN SASARAN}

Kegiatan pengabdian ini terselenggara berkat kerja sama antara perguruan tinggi pengusul dengan pihak kelompok mitra usaha di Dusun Batjoja. Kegiatan penyuluhan dan pendampingan ini merupakan salah satu tahapan penting dari kegiatan pengabdian kepada masyarakat yang merupakan bagian dari Tri Dharma Perguruan tinggi. Pendampingan dan pelatihan dilakukan di Dusun Batjoja Desa Meilepet Kecamatan Siberut Selatan. Dalam pelaksanaannya kegiatan pendampingan kepada kelompok mitra ini mendapat dukungan penuh mulai dari unsur Kecamatan sampai dengan perangkat Desa. Sebagai wujud dari kegiatan pengabdian ini melahirkan sebuah kelompok mitra usaha kerajinan inu dan kerupuk sagu Siberut.

Kegiatan pendampingan dan pelatihan diberikan dengan memberikan penyuluhan dengan metode ceramah dan bimbingan yang bermaksud untuk memotivasi kelompok mitra untuk mengembangkan hasil usaha mereka dan juga meningkatkan potensi sumber daya yang mereka miliki dalam hal ini juga bagaimana mitra mempertahankan kearifan budaya lokal yang mereka miliki. Sumber daya yang terpenting dimiliki oleh kelompok mitra yaitu sumberdaya yang dimiliki oleh masyarakat Dusun Batjoja dalam pengembangan ekonomi keluarga.

Tabel 1. Uraian Kegiatan PKM (Langkah-langkah Solusi atas Persoalan Mitra)

\begin{tabular}{|c|c|c|c|c|c|c|}
\hline No & Uraian Kegiatan & Lokasi & Waktu & Sarana & $\begin{array}{l}\text { Jumlah } \\
\text { Peserta }\end{array}$ & Partisipasi Mitra \\
\hline 1 & Observasi Mitra & $\begin{array}{l}\text { Dusun } \\
\text { Batjoja }\end{array}$ & Bulan 1 & Catatan & & $\begin{array}{l}\text { Memberikan data } \\
\text { dan informasi } \\
\text { kegiatan }\end{array}$ \\
\hline 2 & $\begin{array}{l}\text { Sosialisasi tim pengabdian } \\
\text { kepada Mitra tentang kegiatan } \\
\text { peningkatan penjualan, } \\
\text { produksi dan penggunaan }\end{array}$ & $\begin{array}{l}\text { Dusun } \\
\text { Batjoja }\end{array}$ & Bulan 1 & LCD, chart & 13 & $\begin{array}{l}\text { Terlibat dalam } \\
\text { kegiatan sosialisasi }\end{array}$ \\
\hline
\end{tabular}




\begin{tabular}{|c|c|c|c|c|c|c|}
\hline No & Uraian Kegiatan & Lokasi & Waktu & Sarana & $\begin{array}{l}\text { Jumlah } \\
\text { Peserta }\end{array}$ & Partisipasi Mitra \\
\hline & $\begin{array}{l}\text { media Ecommerece Sebagai } \\
\text { sarana pemasaran }\end{array}$ & & & & & \\
\hline 3 & $\begin{array}{l}\text { Bimbingan \& pendampingan } \\
\text { Proses kerajinan inu }\end{array}$ & $\begin{array}{l}\text { Dusun } \\
\text { Batjoja }\end{array}$ & Bulan 2 & $\begin{array}{l}\text { Flip chart, } \\
\text { catatan, ATK }\end{array}$ & 13 & $\begin{array}{l}\text { Terlibat dalam } \\
\text { kegiatan }\end{array}$ \\
\hline 4 & $\begin{array}{l}\text { Bimbingan \& pendampingan } \\
\text { pemilihan bahan atau peralatan } \\
\text { proses produksi kerupuk sagu }\end{array}$ & $\begin{array}{l}\text { Dusun } \\
\text { Batjoja }\end{array}$ & Bulan 2 & $\begin{array}{l}\text { Flip chart, } \\
\text { timbangan } \\
\text { dapur, bahan } \\
\text { makanan, } \\
\text { catatan, ATK }\end{array}$ & 13 & $\begin{array}{l}\text { Terlibat dalam } \\
\text { kegiatan } \\
\text { pendampingan }\end{array}$ \\
\hline 5 & $\begin{array}{l}\text { Bimbingan \& pendampingan } \\
\text { pengolahan \& perbaikan proses } \\
\text { produksi }\end{array}$ & $\begin{array}{l}\text { Dusun } \\
\text { Batjoja }\end{array}$ & Bulan 3, & $\begin{array}{l}\text { Alat-alat, } \\
\text { bahan baku } \\
\text { resep }\end{array}$ & 13 & $\begin{array}{l}\text { Menyiapkan lokasi } \\
\text { dan keperluan } \\
\text { untuk produksi, } \\
\text { Terlibat dalam } \\
\text { kegiatan }\end{array}$ \\
\hline 6 & $\begin{array}{l}\text { Bimbingan \& pendampingan } \\
\text { manajemen usaha: Pengemasan } \\
\text { kerupuk sagu dan kerajinan inu } \\
\text { Manajemen pemasaran produk }\end{array}$ & $\begin{array}{l}\text { Dusun } \\
\text { Batjoja }\end{array}$ & $\underset{5}{\text { Bulan }} 4$ & $\begin{array}{l}\text { Kemasan } \\
\text { produk, } \\
\text { catatan } \\
\text { informasi } \\
\text { produksi, } \\
\text { ATK, }\end{array}$ & 13 & $\begin{array}{l}\text { Terlibat dalam } \\
\text { kegiatan }\end{array}$ \\
\hline 7 & $\begin{array}{l}\text { Pemasaran produk membuat } \\
\text { market place berupa } \\
\text { penggunaan media Ecommerce } \\
\text { dalam saluran pemasaran }\end{array}$ & $\begin{array}{l}\text { Dusun } \\
\text { Batjoja }\end{array}$ & Bulan 5 & Booth, produk & 13 & $\begin{array}{l}\text { Terlibat dalam } \\
\text { kegiatan }\end{array}$ \\
\hline 8 & $\begin{array}{l}\text { Monitoring dan evaluasi } \\
\text { kegiatan }\end{array}$ & $\begin{array}{l}\text { Dusun } \\
\text { Batjoja }\end{array}$ & Bulan 5 & LCD, catatan & 13 & $\begin{array}{l}\text { Terlibat dalam } \\
\text { kegiatan }\end{array}$ \\
\hline
\end{tabular}

Luaran yang akan di dapatkan dalam kegiatan ini adalah berupa perbaikan proses produksi serta proses penjualan dan pemanfaatan sumberdaya dalam berkegiatan serta memilih saluran pemasaran yang tepat dengan menggunakan e-commerce sebagai media online. Dalam hal ini setidaknya ada beberapa bagian penting dalam industri yang dihasilkan oleh kelompok usaha dari masyarakat mitra di Dusun Batjoja yakninya:

1. Kreativitas dan bakat yang dimiliki serta kemauan kelompok masyarakat di Dusun Batjoja.

2. Karya atau produk yang dihasilkan oleh kelompok mitra bisa memberikan kontribusi bagi pihak Desa ataupun pihak Kecamatan.

3. Keuntungan tertentu, yakni terdiri dari pendapatan kelompok ataupun individu, kemakmuran, perluasan jaringan, peningkatan status sosial tertentu dan lain sebagainya.

Namun dalam perlaksanaan kegiatan yang telah dilakukan, dalam pendampingan dan pelatihan yang diberikan terdapat kendala oleh kelompok mitra Dusun Batjoja adalah kurangnya akses internet sehingga dalam pemilihan saluran pemasaran dalam pemanfaatan media ecommerce tidak bisa terlaksana dengan baik dan lancar sehingga media promosi online tidak berjalankan dengan baik. Namun kegiatan pemasaran secara langsung tetap berjalan dengan baik, salah satunya dengan memanfaatkan berbagai iven yang dilakukan sehingga beberapa produk yang dihasilkan dapat terjual dan bisa diperkenalkan kepada masyarakat lokal ataupun masyarakat mancanegara. Berikut beberapa kegiatan yang didokumentasikan: 


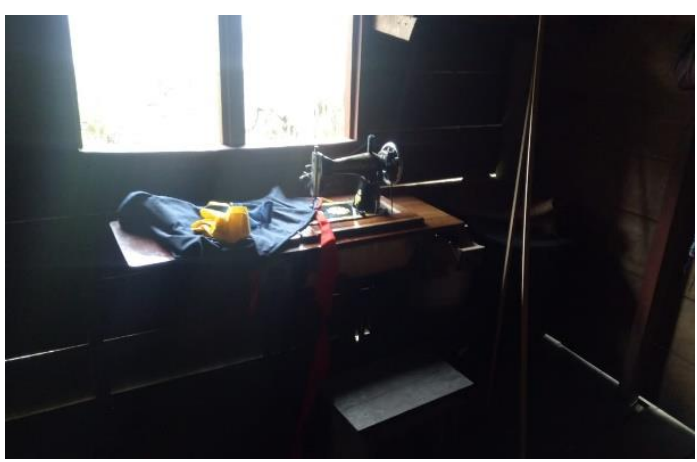

Gambar 1. Peralatan yang biasa digunakan oleh kelompok mitra



Gambar 3. Aktivitas kelompok mitra dalam membuat inu



Gambar 5. Adonan Kerupuk sagu selesai siap utk dikeringkan

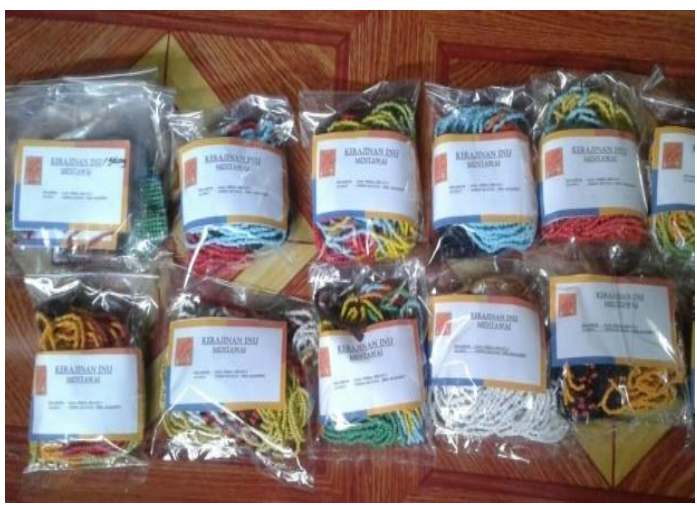

Gambar 7. Kerajinan Inu selesai diproduksi

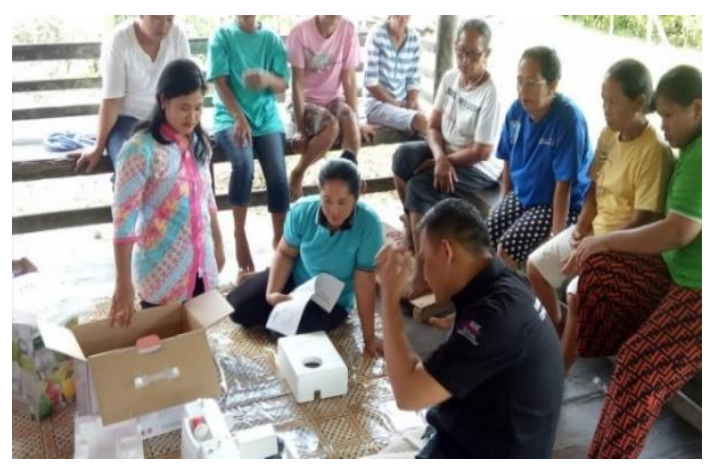

Gambar 2. pengenalan barang-barang penunjang produksi



Gambar 4. Kegiatan pendampingan yang dilakukan oleh tim PKM



Gambar 6. Kerupuk sagu siap untuk di packing

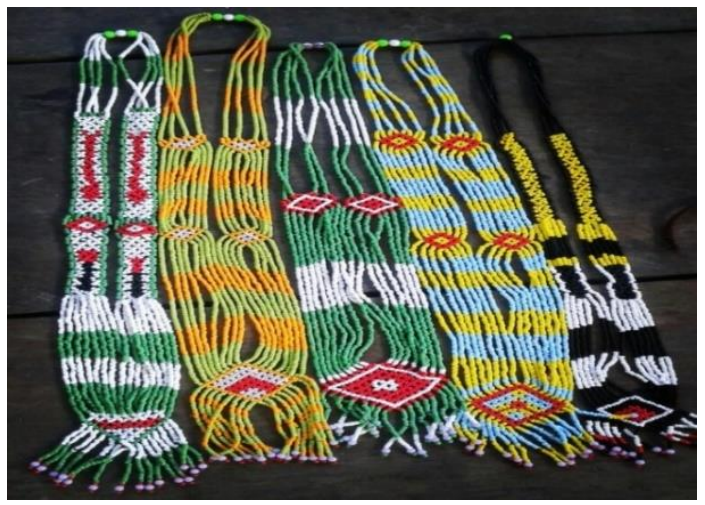

Gambar 8. Kerajinan Inu siap untuk dipasarkan 




Gambar 9. Kerupuk sagu selesai di packing dan siap`untuk dipasarkan



Gambar 11. Pondok Promosi yang akan dipakai untuk pergelaran produk

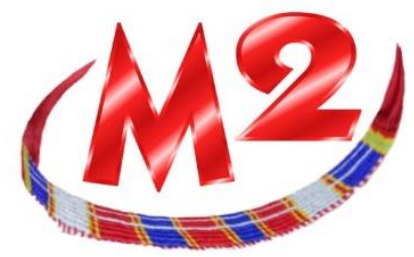

Gambar 13. Logo atau lambang dari kelompok mitra

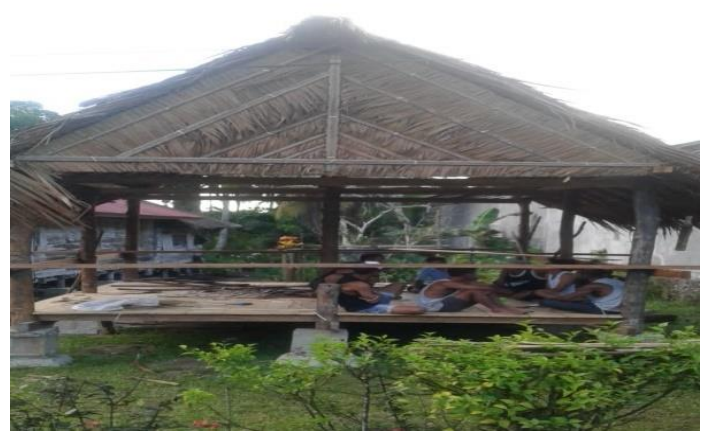

Gambar 10. Kerajinan sabe siap dipasarkan

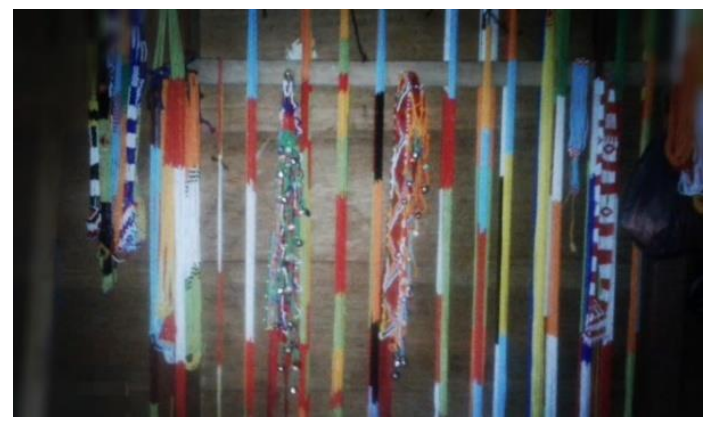

Gambar 12. Bermacam Kerajinan Inu selesai produksi

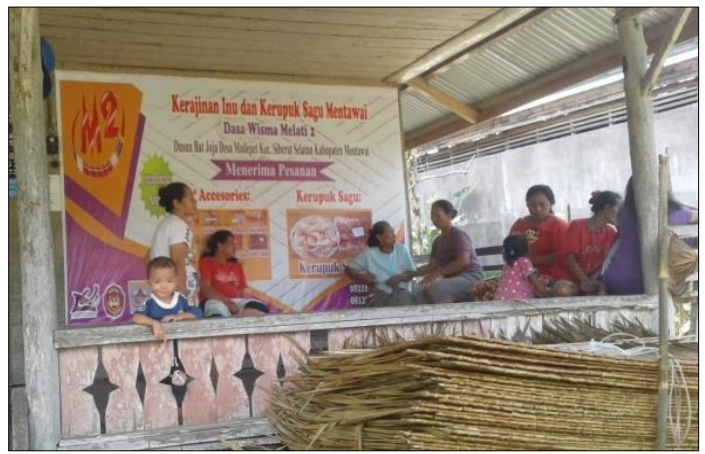

Gambar 14. kelompok mitra selesai berkegiatan

Oleh karena itu dalam mengembangkan industri rumahan harus dimulai dari bagaimana kelompok mitra mampu untuk mengeluarkan ide dan kraetivitas, kemauan, bakat, potensi dan kemampuan anggota kelompok dalam menjalankan aktivitasnya. Pada kegiatan pengabdian yang telah dilakukan kelompok mitra Sangat bersemangat dalam melakukan setiap kegiatan, namun hanya saja dalam memulai mereka Sangat bertumpu pada hasil dari kegiatan yang sebelumnya. Berdasarkan pengamatan yang telah dilakukan di lapangan dapat dilihat beberapa kondisi diantaranya:

Tabel 2. Aktivitas yang teridentifikasi dilapangan

\begin{tabular}{lcccccc}
\hline & Tenaga Kerja & Modal & Keahlian & Pemberdayaan & Semangat bekerja & pemasaran \\
\hline Bagus & $\sqrt{ }$ & & $\sqrt{ }$ & & $\sqrt{ }$ \\
Cukup & & & $\sqrt{ }$ & \\
Sedang & & & & & $\sqrt{ }$ \\
Kurang & & $\sqrt{ }$ & & & \\
\end{tabular}


Dari tabel 2 diatas, dapat dilihat bahwasanya ada dua hal prioritas yang dapat dibutuhkan dan dikembangkan dalam meningkatkan penghasilan dan pemberdayaan kelompok mitra adalah bagaimana memaksimalkan modal yang dimiliki, dalam artian bahwasannya kelompok mitra harus lebih meningkatkan potensi yang dimiliki disamping besaran uang yang harus disediakan untuk mengembangkan usaha. Serta, kegiatan pemasaran dimana akses dari pemasaran secara elektronik menjadi kendala utama dikarenakan akses internet di wilayah dusun batjoja Sangat terbatas dan sulit sehingga kegiatan yang telah berjalan memang hanya terkendala dalam memasarkan produk secara online.

\section{KESIMPULAN}

Kelompok usaha yang dijalankan mitra Sangat berpotensi dalam menghasilkan nilai dan uang. Meskipun penjualan dari produk yang dihasilkan yakni kerajinan inu dan kerupuk sagu sudah semakin bagus secara lokal namun pemerataan penjualan dan pemasaran produk masih Sangat minim sehingga dalam peningkatan ekonomi keluarga masih perlu ditingkatkan lagi. Hal ini juga didasari oleh lemahnya informasi dan edukasi yang dimiliki oleh kelompok mitra dalam hal proses produksi dan pemilihan pemasaran.

Dengan pengembangan yang dilakukan berjalan secara opimal dan berkelanjutan sesuai dengan kemampuan, kemauan, bakat dan potensi yang dimilik oleh kelompok mitra. Untuk itu kedepannya diperlukan lagi keberlanjutan pendampingan guna mengoptimalisasikan setiap faktor penting dalam pengembangan kerajinan dan usaha kelompok untuk keberlangsungan hidup keluarga serta daya tarik desa yang ada di Meillepet. Peran yang diberikan oleh pemerintah Kecamatan harus mampu di maksimalkan bagi anggota mitra guna keberlanjutan kelompok usaha untuk pengembangan ke Nasional ataupun Mancanegara.

\section{UCAPAN TERIMA KASIH}

Ucapan terima kasih kepada Direktorat Riset dan Pengabdian Masyarakat Direktorat Jendral Penguatan Riset dan Pengembangan Kementrian Riset, Teknologi, dan Pendidikan Tinggi sesuai dengan Kontrak program Pengabdian Masyarakat tahun Anggaran 2019 antara Direktorat Riset dan Pengabdian Masyarakat dengan Kopertis Wilayah X Nomor 114/SP2H/PPM/DRPM/2019.

\section{DAFTAR PUSTAKA}

Anggraeni, F. D., I. Hardjanto, \& A. Hayat. 2013. Pengembangan Usaha Mikro, Kecil, dan Menengah (UMKM) Melalui Fasilitas Pihak Eksternal dan Potensi Internal. Jurnal Administrasi Publik 1(6): 1286-1295.

Darwanto. 2013. Peningkatan Daya Saing UMKM Berbasis Inovasi dan Kreativitas. Jurnal Bisnis dan Ekonomi 20(2): 142-149.

Fithri, D. L., A. P. Utomo, \& F. Nugraha. 2017. Pemanfaatan E-Commerce Populer Untuk Optimalisasi. Jurnal Simetris 8(2): 819-824.

Harto, D., S. R. Pratiwi, M. N. Utomo, \& M. Rahmawati. 2019. Penerapan Internet Marketing dalam Meningkatkan Internet Marketing Implementation.

Kosasi, S. 2015. Perancangan Sistem E-Commerce Untuk Memperluas Pasar Produk Oleh-oleh Khas Pontianak. Snastia: $110-119$.

Maulana, S. M., H. Susilo, \& Riyadi. 2015. Implementasi E-Commerce sebagai Media Penjualan Online. Jurnal Administrasi Bisnis (JAB) 29(1): 1-9.

Murdani, S., H. Widayani. 2019. Pengembangan Ekonomi Masyarakat Melalui Pemberdayaan Usaha Mikro Kecil dan Menengah (Studi di Kelurahan Kandri Kecamatan Gunungpati Kota Semarang) 23(2): 152-157.

Pattinama, M. J. 2009. Pengentasan Kemiskinan Dengan Kearifan Lokal (Studi Kasus di Pulau Buru-Maluku dan Surade-Jawa Barat), Jurnal Makara Sosial Humaniora 13(1): 1-12.

Sahudiyono. 2009. Memberdayakan Masyarakat Pesisir dengan Pendekatan Program Pemberdayaan Ekonomi Masyarakat Pesisir (PEMP). Jurnal Riset Daerah BAPEDA Bantul 7(3): 1169-1189. 